\title{
Grignard Reagent-Mediated Conversion of an Acyl Nitroso- Anthracene Cycloadduct to a Nitrone
}

\author{
Weibin Chen, Cynthia S. Day, and S. Bruce King \\ Department of Chemistry, Wake Forest University, Winston-Salem, NC 27109, USA \\ S. Bruce King: kingsb@wfu.edu
}

\begin{abstract}
An intramolecular hetero-Diels-Alder cycloadduct of an acyl nitroso compound and a 9, 10dimethyl anthracene derivative was prepared as a potential nitroxyl (HNO) donor. This compound did not release HNO under any of the conditions tested. Treatment of this cycloadduct with excess $\mathrm{MeMgCl}$ resulted in the formation of a nitrone, whose structure was confirmed by X-ray crystallography. A mechanism where $\mathrm{MeMgCl}$ acts as a nucleophile, strong base and Lewis acid possibly explains the formation of this product.
\end{abstract}

The cycloadducts of acyl nitroso compounds and 9,10-dimethylanthracene (1, Scheme 1) undergo thermal decomposition through retro-Diels-Alder reactions to produce acyl nitroso compounds $(\mathbf{2}$, Scheme 1$)$ under non-oxidative conditions and relatively mild temperatures $\left(40-100^{\circ} \mathrm{C}\right) .{ }^{1-4}$ Decomposition of these compounds provides a particularly clean method for the formation of acyl nitroso compounds, which are highly reactive $\mathrm{N}-\mathrm{O}$ heterodienophiles. Acyl nitroso compounds also hydrolyze to release nitroxyl (HNO), the one-electron reduced form of the biologically important messenger molecule, nitric oxide (NO) ${ }^{5-9}$ Nitroxyl has drawn considerable recent interest as it demonstrates distinct biological effects to NO in various systems. ${ }^{10,11}$ Such activities and the inherent chemical instability of HNO also have focused efforts on the development of chemically and mechanistically unique nitroxyl releasing systems.

Our recent studies show $\mathrm{HNO}$ release from functionalized N-hydroxyurea-derived acyl nitroso-9, 10-dimethylanthracene cycloadducts $(1, \mathrm{R}=-\mathrm{NHR})$ through the pathway depicted in Scheme $1 .{ }^{12,13}$ Generation of an equivalent of the water-insoluble and immunotoxic 9 , 10-dimethylanthracene $(\mathbf{3}, 9,10$-DMA) in this sequence remains a major limitation of this method of HNO formation. ${ }^{14}$ The introduction of functional groups that act as hydrogenbond donors or acceptors on the 9, 10-DMA portion of these molecules should increase water solubility and reduce toxicity. ${ }^{15}$ Compound $\mathbf{4}$, the product of an intramolecular heteroDiels-Alder reaction of acyl nitroso compound (5), fulfills this requirement by producing the carboxylic acid (6) after retro-Diels-Alder reaction and hydrolysis (Scheme 1). We wish to report the preparation of $\mathbf{4}$, its ability to act as an HNO donor and a unique molecular rearrangement upon treatment with an excess amount of Grignard reagent.

Scheme 2 depicts the synthesis of the target compound 4. Horner-Wadsworth-Emmons olefination of commercially available 10-methylanthracene-9-carboxaldehyde (7) yields a mixture of the $a, \beta$-unsaturated esters $\mathbf{8}$ and $\mathbf{9}(\mathbf{8 : 9}=5.8: 1,92 \%$ overall yield, Scheme 2$)$.

Correspondence to: S. Bruce King, kingsb@wfu. edu.

Supporting Information Available. Copies of the ${ }^{1} \mathrm{H}$ and ${ }^{13} \mathrm{C}$ NMR spectra of the synthetic intermediates and final products are included. Crystallographic Information Files (CIF) for $\mathbf{4}$ and $\mathbf{1 4}$ are also included. This material is free of charge via the Internet at http://pubs.acs.org 
Reduction of 8 and 9 proved difficult with $\mathrm{NaBH}_{4} / \mathrm{NiCl}_{2}$ and hydrogenation on $\mathrm{Pd} / \mathrm{C}$ yielding mixtures as a result of the concurrent reduction of the anthracene moiety. ${ }^{16,17}$ However, $\mathrm{Pd}(\mathrm{OAc})_{2} / \mathrm{HCO}_{2} \mathrm{~K}$ in DMF at $50{ }^{\circ} \mathrm{C}$ selectively reduces 8 and 9 to 10 in quantitative yield. ${ }^{18}$ Condensation of $\mathbf{1 0}$ with $\mathrm{NH}_{2} \mathrm{OH}$ hydrochloride/KOH gives hydroxamic acid (11) in $85 \%$ yield at $-10{ }^{\circ} \mathrm{C} .{ }^{19}$ Tetra-n-butylammonium periodate oxidation of $\mathbf{1 1}$ at $0{ }^{\circ} \mathrm{C}$ produces $\mathbf{4}$ through an intramolecular-Diels-Alder reaction of the highly reactive acyl nitroso compound intermediate (5, Scheme 2). ${ }^{19,20}$ The structure of $\mathbf{4}$ was assigned unambiguously by single crystal X-ray diffraction analysis (Supporting Information).

The preparation of $\mathbf{4}$ allows the investigation of the ability of this compound to release $\mathrm{HNO}$ through thermal decomposition. Identification of nitrous oxide $\left(\mathrm{N}_{2} \mathrm{O}\right)$, the dimerization and dehydration product of $\mathrm{HNO}$, provides strong evidence for the intermediacy of HNO. ${ }^{21}$ Gas chromatographic headspace analysis of the thermal decomposition of $\mathbf{4}$ in a 1:1 mixture of water-acetonitrile at $40{ }^{\circ} \mathrm{C}$ fails to detect the formation of any $\mathrm{N}_{2} \mathrm{O}$, as a measure of $\mathrm{HNO}$. TLC and NMR analysis shows only $\mathbf{4}$ in the reaction mixture. Similar reactions at higher temperatures $\left(60^{\circ} \mathrm{C}, 80^{\circ} \mathrm{C}\right.$ and $\left.100{ }^{\circ} \mathrm{C}\right)$ also fail to generate $\mathrm{N}_{2} \mathrm{O}$, indicating the stability of 4. Treatment of 4 with $\mathrm{NaOH}(1.0 \mathrm{~N})$ at $80{ }^{\circ} \mathrm{C}$ for $10 \mathrm{~h}$ partially converts 4 to 6 in $11 \%$ yield, but no $\mathrm{N}_{2} \mathrm{O}$ was detected. While cycloadducts of acyl nitroso compounds derived from hydroxamic acids generally show greater stability than those derived from $\mathrm{N}$ hydroxyureas, such cycloadducts should decompose at these temperatures. ${ }^{1-4}$ These results highlight the preference for the intramolecular cycloadduct (4) over the acyl nitroso compound (5) in this system. The failure of $\mathbf{4}$ to release HNO under these conditions prompted further structural elaboration. ${ }^{5}$

Cycloadducts similar to $\mathbf{4}$ have been recognized as bicyclic forms of Weinreb amides. ${ }^{22}$ Previous work shows that the addition of Grignard reagents to 1,3-cyclopentadiene-acyl nitroso compound derived cycloadducts in the presence of catalytic copper salts results in regiospecific ring opening of the bicyclic system (and not attack at the amide with ketone formation). ${ }^{26}$ However, such reactions with 9, 10-DMA-acyl nitroso cycloadducts have not been reported and we wished to explore the possibility of Grignard reagent $(\mathrm{MeMgCl})$ attack of the carbonyl group to yield unique acyl nitroso-anthracene derived cycloadducts as possible HNO donors. Such a reaction would yield a ketone (12) that in the presence of excess Grignard reagent would further react to give an alcohol (13, Scheme 3). Both 12 and $\mathbf{1 3}$ meet the previously mentioned requirements of potentially improved HNO donors that would release functionalized versions of 9, 10-DMA upon retro-Diels-Alder decomposition. Treatment of $\mathbf{4}$ with one or two equivalents of $\mathrm{MeMgCl}$ yields a complex mixture of products by TLC. Surprisingly, treatment of $\mathbf{4}$ with excess $\mathrm{MeMgCl}$ gives a solid product that single crystal X-ray diffraction studies reveal as the nitrone (14, Scheme 3) in 76\% yield. In addition to the unambiguous $\mathrm{X}$-ray diffraction analysis (Figure 1), the structure of 14 is supported by both ${ }^{1} \mathrm{H}$ and ${ }^{13} \mathrm{C}$ NMR (including DEPT experiments that show six $\mathrm{CH}_{2}$ groups ( $\delta 20.49,30.42,36.42,37.34,40.27,110.80 \mathrm{ppm})$ ), elemental analysis, and mass spectrometry (Supporting Information).

The structure of $\mathbf{1 4}$ appears to be a combination of two anthracene-derived cycloadducts with the addition of two methyl groups. The exocyclic double bond of the anthracene moiety depicted in the left part of the molecule (Figure 1) may arise from a $\mathrm{Mg}$ (II)-mediated ring opening of $\mathbf{4}$. To confirm this idea, treatment of $\mathbf{4}$ with $\mathrm{MgI}_{2}$ (prepared from $\mathrm{I}_{2}$ and $\mathrm{Mg}$ in ether) yields a red solution that was purified by flash chromatography on silica gel to give hydroxamic acid (16, Scheme 4) as a white solid in a quantitative yield. The red color may reflect a complex of $\mathbf{1 6}$ with $\mathrm{Mg}$ (II) or possibly small amounts of the nitroxide radical of 16. The formation of the intermediate carbocation $\mathbf{1 5}$, stabilized by two phenyl groups, likely represents the driving force for this skeletal rearrangement of $4 .^{23-26}$ 
While the crystallographic studies confirm the structure of $\mathbf{1 4}$, a mechanism for its formation remains unclear. Scheme 5 depicts a possible pathway that combines nucleophilic attack of $\mathrm{MeMgCl}$ on the carbonyl group of $\mathbf{4}$ with $\mathrm{Mg}$ (II)-mediated ring opening of $\mathbf{4}$ to $\mathbf{1 6}$. Initial nucleophilic attack of the carbonyl group of 4 by $\mathrm{MeMgCl}$ would yield 17 that may be susceptible to a second attack by $\mathrm{MeMgCl}$ (possibly through an iminium ion-like intermediate) to give 18. Simultaneously, $\mathrm{Mg}$ (II)-mediated opening of $\mathbf{4}$ would yield $\mathbf{1 6}$ as supported by the previously described reactions with $\mathrm{MgI}_{2}$. Reaction of 18 with a third equivalent of $\mathrm{MeMgCl}$ acting as a base could produce a new Grignard species (19, Scheme 5) that could condense with $\mathbf{1 6}$ to give intermediate (20, Scheme 5). Final loss of $-\mathrm{OMgCl}$ (or water) from 20 would yield 14. This mechanism suggests three roles for $\mathrm{MeMgCl}: 1$ ) carbon nucleophile, 2) strong base and 3) Lewis acid. The formation of the new Grignard species $\mathbf{1 9}$ may be facilitated by coordination of $\mathrm{Mg}$ (II) to oxygen to form a five-membered ring (Scheme 5).

In summary, compound 4, the product of an intramolecular hetero-Diels-Alder reaction of an acyl nitroso compound and a 9,10-dimethyl anthracene derivative was prepared using straightforward synthetic schemes. However, 4 did not undergo facile retro-Diels-Alder decomposition and did not act as an HNO donor under any of the conditions tested. Treatment of $\mathbf{4}$ with excess $\mathrm{MeMgCl}$ resulted in the formation of a unique nitrone (14), whose structure has been unambiguously confirmed by X-ray crystallography. Tentatively, a mechanism in which the Grignard reagent acts as a nucleophile, strong base and Lewis acid has been forwarded as a possible explanation for the formation of this unusual product.

\section{Experimental}

\section{9-[2'-(Ethoxycarbonyl)vinyl]-10-methylanthracenes (8) and (9)}

A solution of triethyl phosphonoacetate $(12 \mathrm{~g}, 53.6 \mathrm{mmol})$ in DME $(12 \mathrm{~mL})$ was added dropwise to a stirred suspension of $\mathrm{NaH}(1.32 \mathrm{~g}, 55.0 \mathrm{mmol})$ in dry DME $(40 \mathrm{~mL})$ at $0{ }^{\circ} \mathrm{C}$. After stirring at $\mathrm{rt}$ for $2 \mathrm{~h}, 10$-methylanthracene-9-carboxaldehyde $(2.5 \mathrm{~g}, 11.4 \mathrm{mmol})$ was added in one portion and the reaction mixture stirred at $50{ }^{\circ} \mathrm{C}$ for $4 \mathrm{~h}$. After cooling, the reaction was quenched with water and extracted with ethyl acetate. The organic layer was washed with brine, dried over $\mathrm{Na}_{2} \mathrm{SO}_{4}$, concentrated and the residue purified by flash chromatography on silica gel (gradient: $3 \%$ to $10 \%$ ethyl acetate in hexane) to give a mixture (5.8:1) of esters 8 and $\mathbf{9}(3.04 \mathrm{~g}, 92 \%)$ as a yellow solid. 8: ${ }^{1} \mathrm{H}$ NMR $(300 \mathrm{MHz}$, $\left.\mathrm{CDCl}_{3}\right) \delta 8.64(\mathrm{~d}, \mathrm{~J}=16.2 \mathrm{~Hz}, 1 \mathrm{H}), 8.23-8.56(\mathrm{~m}, 4 \mathrm{H}), 7.47-7.58(\mathrm{~m}, 4 \mathrm{H}), 6.38(\mathrm{~d}, \mathrm{~J}=16.2$ $\mathrm{Hz}, 1 \mathrm{H}), 4.40$ (q, J = 7.2 Hz, 2H), 3.11 (s, 3H), 1.44 (t, J=7.2 Hz, 3H).

\section{9-[2'-(Ethoxycarbonyl)ethyl]-10-methylanthracene (10)}

A mixture of 8 and $9(0.77 \mathrm{~g}, 2.65 \mathrm{mmol}), \mathrm{HCO}_{2} \mathrm{~K}(4.2 \mathrm{~g}, 50 \mathrm{mmol}), \mathrm{Pd}(\mathrm{OAc})_{2}(12 \mathrm{mg}$, $0.05 \mathrm{mmol})$ and DMF $(10 \mathrm{~mL})$ was stirred in a sealed glass tube under argon at $50{ }^{\circ} \mathrm{C}$ for 18 h. After cooling, the reaction mixture was diluted with ethyl acetate and filtered through Celite, which was washed with additional ethyl acetate. This organic filtrate was washed with water and brine, and the organic phase dried over $\mathrm{Na}_{2} \mathrm{SO}_{4}$. After concentration, water was added to this DMF-contaminated residue to give a solid, which was filtered and dried to afford $10(0.76 \mathrm{~g}, 98 \%)$ as a white solid. ${ }^{1} \mathrm{H}$ NMR $\left(300 \mathrm{MHz}, \mathrm{CDCl}_{3}\right) \delta 8.28-8.38(\mathrm{~m}, 4 \mathrm{H})$, 7.48-7.58 (m, 4H), $4.21(\mathrm{q}, \mathrm{J}=7.2 \mathrm{~Hz}, 2 \mathrm{H}), 3.97(\mathrm{t}, \mathrm{J}=8.5 \mathrm{~Hz}, 2 \mathrm{H}), 3.11(\mathrm{~s}, 3 \mathrm{H}), 2.78$ (t, J $=8.3 \mathrm{~Hz}, 2 \mathrm{H}), 1.28(\mathrm{t}, \mathrm{J}=7.2 \mathrm{~Hz}, 3 \mathrm{H})$.

\section{N-hydroxy-3-(10-methylanthracen-9-yl)propanamide (11)}

A solution of $\mathrm{KOH}(4.31 \mathrm{~g}, 77.0 \mathrm{mmol})$ in $\mathrm{MeOH}(15 \mathrm{~mL})$ was added dropwise to a solution of hydroxylamine hydrochloride $(2.67 \mathrm{~g}, 38.4 \mathrm{mmol})$ in $\mathrm{MeOH}(10 \mathrm{~mL})$ at $-10{ }^{\circ} \mathrm{C}$ and the mixture was stirred $30 \mathrm{~min}$. A solution of $\mathbf{1 0}(1.12 \mathrm{~g}, 3.84 \mathrm{mmol})$ in $\mathrm{MeOH}(5 \mathrm{~mL})$ was 
added dropwise and this white suspension stirred overnight at $-10{ }^{\circ} \mathrm{C}$. At this time, water was added to the mixture and the $\mathrm{pH}$ was adjusted to 6 with concentrated $\mathrm{HCl}$. The mixture was extracted with ethyl acetate and the extracts were dried over $\mathrm{Na}_{2} \mathrm{SO}_{4}$, concentrated, and the residue purified by flash chromatography on silica gel (gradient: $2 \%$ to $10 \% \mathrm{MeOH}$ in $\left.\mathrm{CH}_{2} \mathrm{Cl}_{2}\right)$ to afford $\mathbf{1 1}(0.91 \mathrm{~g}, 85 \%)$ as a pale yellow powder. mp $112.0-115.0{ }^{\circ} \mathrm{C} .{ }^{1} \mathrm{H}$ NMR (300 MHz, $\left.\left(\mathrm{CD}_{3}\right)_{2} \mathrm{SO}\right) \delta 10.54(\mathrm{~s}, 1 \mathrm{H}), 8.82(\mathrm{~s}, 1 \mathrm{H}), 8.31-8.43(\mathrm{~m}, 4 \mathrm{H}), 7.52-7.63(\mathrm{~m}, 4 \mathrm{H})$, $3.82(\mathrm{t}, \mathrm{J}=8.1 \mathrm{~Hz}, 2 \mathrm{H}), 3.05(\mathrm{~s}, 3 \mathrm{H}), 2.40(\mathrm{t}, \mathrm{J}=8.1 \mathrm{~Hz}, 2 \mathrm{H}) .{ }^{13} \mathrm{C}$ NMR $(75 \mathrm{MHz}$, $\left.\left(\mathrm{CD}_{3}\right)_{2} \mathrm{SO}\right) \delta 168.3,131.5,129.5,129.0,128.7,125.49,125.46,125.0,124.6,34.0,23.6$, 13.9. ESIMS $\mathrm{m} / \mathrm{z} 278\left(\mathrm{M}^{+}-1,100 \%\right)$. Anal. Calcd for $\mathrm{C}_{18} \mathrm{H}_{17} \mathrm{NO}_{2} \cdot 0.5 \mathrm{H}_{2} \mathrm{O}: \mathrm{C}, 75.00 ; \mathrm{H}$, 6.25; N, 4.86. Found: C, 74.67; H, 6.19; N, 4.66.

\section{Cycloadduct (4)}

A solution of $\mathbf{1 1}(0.4 \mathrm{~g}, 1.43 \mathrm{mmol})$ in $\mathrm{MeOH}: \mathrm{CH}_{2} \mathrm{Cl}_{2}: \mathrm{H}_{2} \mathrm{O}(1: 1: 0.1,21 \mathrm{~mL})$ was added to a solution of tetra-n-butylammonium periodate $(1.24 \mathrm{~g}, 2.86 \mathrm{mmol})$ in $\mathrm{MeOH}: \mathrm{CH}_{2} \mathrm{Cl}_{2}(1: 2,15$ $\mathrm{mL}$ ) at $0{ }^{\circ} \mathrm{C}$. The reaction mixture was stirred at $0{ }^{\circ} \mathrm{C}$ for $2 \mathrm{~h}$, quenched with saturated aqueous $\mathrm{Na}_{2} \mathrm{~S}_{2} \mathrm{O}_{3}$ and extracted with $\mathrm{CH}_{2} \mathrm{Cl}_{2}$. The organic layer was washed with brine, dried over $\mathrm{Na}_{2} \mathrm{SO}_{4}$, concentrated and the residue purified by flash chromatography on silica gel (gradient: $40 \%$ to $70 \%$ ethyl acetate in hexane) to give $\mathbf{4}(0.4 \mathrm{~g}, 100 \%)$ as colorless needles. mp 202.0-204.0 ${ }^{\circ} \mathrm{C} .{ }^{1} \mathrm{H}$ NMR (300 MHz, $\left.\mathrm{CDCl}_{3}\right) \delta$ 7.40-7.46 (m, 2H), 7.26-7.36 $(\mathrm{m}, 6 \mathrm{H}), 2.99(\mathrm{t}, \mathrm{J}=8.1 \mathrm{~Hz}, 2 \mathrm{H}), 2.65(\mathrm{t}, \mathrm{J}=8.1 \mathrm{~Hz}, 2 \mathrm{H}), 2.30(\mathrm{~s}, 3 \mathrm{H}) .{ }^{13} \mathrm{C}$ NMR $(75 \mathrm{MHz}$, $\left.\mathrm{CDCl}_{3}\right) \delta 166.1,140.7,139.5,127.8,127.7,121.9,119.7,82.4,65.4,28.6,17.4,14.7$. ESIMS $m / z 278\left(\mathrm{M}^{+}+1,100 \%\right)$. Anal. Calcd for $\mathrm{C}_{18} \mathrm{H}_{15} \mathrm{NO}_{2}$ : C, 77.98; H, 5.42; N, 5.05. Found: C, 78.04; H, 5.44; N, 5.04.

\section{Compound (14)}

A solution of $\mathrm{MeMgCl}(10 \mathrm{~mL}$ of a $3.0 \mathrm{M}$ solution in ether, $30 \mathrm{mmol})$ was added to a stirred solution of $4(138 \mathrm{mg}, 0.5 \mathrm{mmol})$ in dry THF $(20 \mathrm{~mL})$ at $-78{ }^{\circ} \mathrm{C}$. After being stirred for 30 min at $-78{ }^{\circ} \mathrm{C}$, the solution was warmed to $0{ }^{\circ} \mathrm{C}$, and stirred overnight. At this time, the reaction mixture was quenched with saturated aqueous $\mathrm{NH}_{4} \mathrm{Cl}$ and extracted with ether. The organic layer was washed with brine, dried over $\mathrm{Na}_{2} \mathrm{SO}_{4}$, concentrated and the residue purified by flash chromatography on silica gel (gradient: $50 \%$ ethyl acetate in hexane to 100\% ethyl acetate) to give $\mathbf{1 4}(105 \mathrm{mg}, \mathbf{7 6 \%}$ ) as a white powder. Evaporative recrystallization from ethyl acetate/hexane provided crystals suitable for X-ray analysis. $\mathrm{mp}$ 175.0-177.0 ${ }^{\circ} \mathrm{C} .{ }^{1} \mathrm{H}$ NMR $\left(300 \mathrm{MHz}, \mathrm{CDCl}_{3}\right) \delta$ 7.71-7.78 (m, 2H), 7.16-7.41 (m, 14H), $5.74(\mathrm{~s}, 2 \mathrm{H}), 2.58-2.98(\mathrm{~m}, 7 \mathrm{H}), 2.21-2.34(\mathrm{~m}, 1 \mathrm{H}), 2.05-2.19(\mathrm{~m}, 5 \mathrm{H}), \delta 0.69(\mathrm{~s}, 3 \mathrm{H}) .{ }^{13} \mathrm{C}$ NMR (75 MHz, $\left.\mathrm{CDCl}_{3}\right) \delta 150.2,143.6,141.9,140.4,136.1,136.0,134.0,134.0,128.4$, 127.6, 127.1, 126.9, 126.6, 126.4, 124.5, 124.3, 121.5, 121.2, 120.2, 119.6, 110.8, 81.5, 69.1, 65.3, 40.3, 37.3, 36.4, 30.4, 23.9, 20.5, 15.3. ESIMS $\mathrm{m} / \mathrm{z} 573\left(\mathrm{M}^{+}+\mathrm{Na}, 100 \%\right)$. Anal. Calcd for $\mathrm{C}_{38} \mathrm{H}_{34} \mathrm{~N}_{2} \mathrm{O}_{2}$ : C, 82.91; H, 6.18; N, 5.09. Found: C, 82.83; H, 6.23; N, 4.96.

\section{Compound (16)}

A mixture of $\mathrm{I}_{2}(0.25 \mathrm{~g}, 1 \mathrm{mmol}), \mathrm{Mg}$ (small turnings, $\left.0.24 \mathrm{~g}, 10 \mathrm{mmol}\right)$ in dry ether $(20 \mathrm{~mL})$ was stirred at $\mathrm{rt}$ for $4 \mathrm{~h}$, and the excess $\mathrm{Mg}$ was removed by filtration to give a colorless solution of $\mathrm{MgI}_{2}$. This solution of $\mathrm{MgI}_{2}(1 \mathrm{mmol})$ was added to a stirred solution of 4 (138 $\mathrm{mg}, 0.5 \mathrm{mmol})$ in dry THF $(20 \mathrm{~mL})$ at $-78{ }^{\circ} \mathrm{C}$,. After $30 \mathrm{~min}$, the solution was allowed to warm to $0{ }^{\circ} \mathrm{C}$ and stirred for $4 \mathrm{~h}$ to give a red solution. The reaction mixture was washed with saturated aqueous $\mathrm{Na}_{2} \mathrm{~S}_{2} \mathrm{O}_{3}$ and extracted with ether. The organic layer was washed with brine, dried over $\mathrm{Na}_{2} \mathrm{SO}_{4}$, concentrated and the residue purified by flash chromatography on silica gel (gradient: $2 \%$ to $10 \% \mathrm{MeOH}$ in $\mathrm{CH}_{2} \mathrm{Cl}_{2}$ ) to give $\mathbf{1 6}(136 \mathrm{mg}$, $98 \%)$ as a white powder. ${ }^{1} \mathrm{H}$ NMR $\left(300 \mathrm{MHz}, \mathrm{CDCl}_{3}\right) \delta 10.34(\mathrm{br} \mathrm{s}, 1 \mathrm{H}), 7.75-7.81(\mathrm{~m}$, 2H), 7.33-7.54 (m, 6H), $5.77(\mathrm{~s}, 2 \mathrm{H}), 2.56(\mathrm{t}, \mathrm{J}=8.1 \mathrm{~Hz}, 2 \mathrm{H}), 2.16(\mathrm{t}, \mathrm{J}=8.1 \mathrm{~Hz}, 2 \mathrm{H}) .{ }^{13} \mathrm{C}$ 
NMR (75 MHz, $\left.\mathrm{CDCl}_{3}\right) \delta 173.5,140.5,136.6,134.4,128.4,127.7,124.7,123.7,110.9$, 68.7, 35.3, 26.1. ESIMS $\mathrm{m} / \mathrm{z} 278\left(\mathrm{M}^{+}+1,100 \%\right)$. Anal. Calcd for $\mathrm{C}_{18} \mathrm{H}_{15} \mathrm{NO}_{2} \cdot \mathrm{H}_{2} \mathrm{O}: \mathrm{C}$, 73.22 ; H, 5.76; N, 4.75. Found: C, 73.02; H, 5.95; N, 4.83.

\section{Supplementary Material}

Refer to Web version on PubMed Central for supplementary material.

\section{Acknowledgments}

This work was supported by the National Institutes of Health (HL 62198, SBK). The NMR spectrometers used in this work were purchased with partial support from NSF (CHE-9708077) and the North Carolina Biotechnology Center (9703-IDG-1007).

\section{References}

1. Christie CC, Kirby GW, McGuigan H, Mackinnon JWM. J. Chem. Soc. Perkin Trans. I. 1985:24692473.

2. Corrie JET, Kirby GW, Mackinnon JWM. J. Chem. Soc. Perkin Trans. I. 1985:883-886.

3. Kirby GW, Sweeny JG. J. Chem. Soc. Perkin Trans. I. 1981:3250-3254.

4. Kirby GW, McGuigan H, Mackinnon JWM, McLean D, Sharma RP. J. Chem. Soc. Perkin Trans. I. 1985:1437-1442.

5. Murphy ME, Sies H. Proc. Natl. Acad. Sci. U.S.A. 1991; 88:10860-10864. [PubMed: 1961756]

6. Culotta E, Koshland DE Jr. Science. 1992; 258:1862-1865. [PubMed: 1361684]

7. Stamler JS, Singel DJ, Loscalzo J. Science. 1992; 258:1898-1902. [PubMed: 1281928]

8. Feldman PL, Griffith OW, Stuehr DJ. Chem. Eng. News. 1993:26-38.

9. Snyder SH. Nature. 1994; 372:504-505. [PubMed: 7990920]

10. Miranda KM, Nagasawa HT, Toscano JP. Current Topics in Medicinal Chemistry. 2005; 5:649_ 664. [PubMed: 16101426]

11. Fukuto JM, Bartberger MJ, Dutton AS, Paolocci N, Wink DA, Houk KN. Chem. Res. Toxicol. 2005; 18:790-801. [PubMed: 15892572]

12. Xu Y, Alavanja MM, Johnson VL, Yasaki G, King SB. Tetrahedron Lett. 2000; 41:4265-4269.

13. Zeng BB, Huang J, Wright MW, King SB. Bioorg. Med. Chem. Lett. 2004; 14:5565-5568. [PubMed: 15482925]

14. Davila DR, Romero DL, Burchiel SW. Toxicol. Appl. Pharmacol. 1996; 139:333-341. [PubMed: 8806850]

15. Larsen T, Link A. Angew. Chem. Int. Ed. 2005; 44:4432-4434.

16. Bahr N, Güller R, Reymond JL, Lerner RA. J. Am. Chem. Soc. 1996; 118:3550-3555.

17. Koizumi T, Tsutsui K, Tanaka K. Eur. J. Org. Chem. 2003:4528-4532.

18. Zeng BB, King SB. Synthesis. 2002; 16:2335-2337.

19. Chow CP, Shea KJ. J. Am. Chem. Soc. 2005; 127:3678-3679. [PubMed: 15771485]

20. Craig D, López MY. Tetrahedron Lett. 2001; 42:8535-8538.

21. Bonner FT, Hughes MN. Comments Inorg. Chem. 1988; 7:215-234.

22. Hahm S, Weinreb SM. Tetrahedron Lett. 1981; 22:3815.

23. Surman MD, Mulvihill MJ, Miller MJ. J. Org. Chem. 2002; 67:4115-4121. [PubMed: 12054945]

24. Mulvihill MJ, Surman MD, Miller MJ. J. Org. Chem. 1998; 63:4874-4875.

25. Surman MD, Miller MJ. J. Org. Chem. 2001; 66:2466-2469. [PubMed: 11281789]

26. Surman MD, Mulvihill MJ, Miller MJ. Tetrahedron Lett. 2002; 43:1131-1134. 


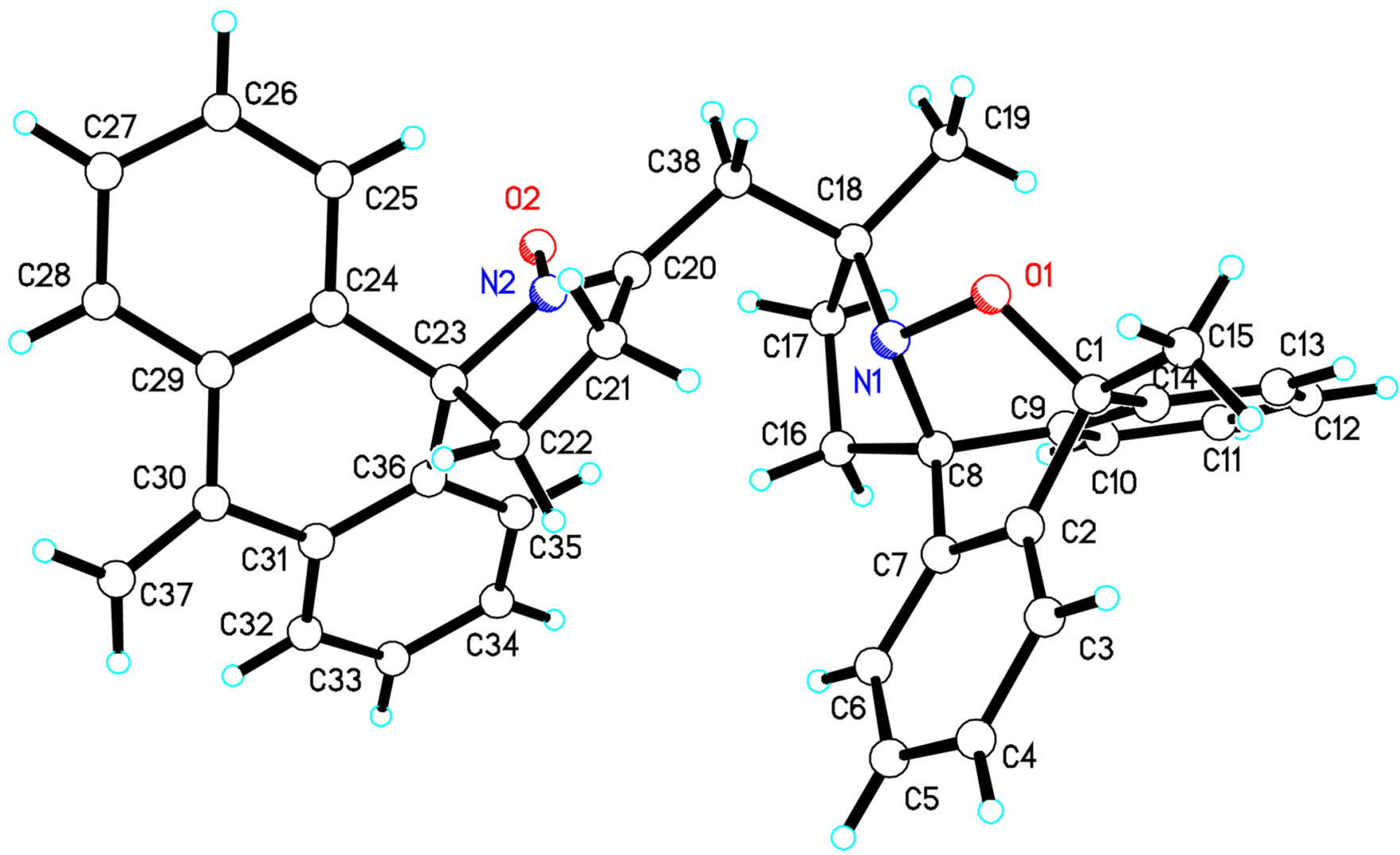

Figure 1.

X-ray crystallographic structure of $\mathbf{1 4}$. 
<smiles>[R]C(=O)N1Oc2ccccc2C1(C)c1ccccc1C</smiles>
R=-alkyl, -aryl, -OR, -NHR

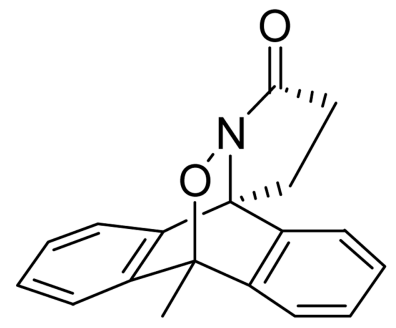

4<smiles>[R]C(=O)[N+](=O)[O-]</smiles><smiles>[R]C(=O)O[CH+]CO[N+](=O)[O-]</smiles>

3<smiles>Cc1c2ccccc2c(CCC(=O)N=O)c2ccccc12</smiles>

5<smiles>Cc1c2ccccc2c(CCC(=O)O)c2ccccc12</smiles>

6

Scheme 1. 
<smiles>[Z]c1c2ccccc2c(C=O)c2ccc(N[P](OCC)(OCC)OCC(=O)OCC)cc12</smiles>

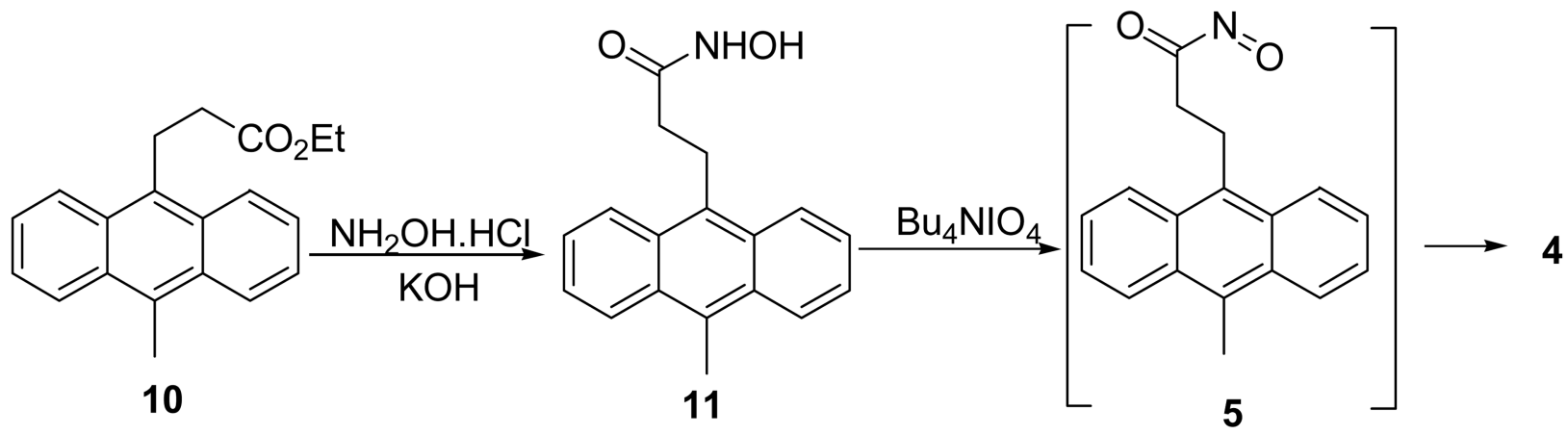

Scheme 2. 


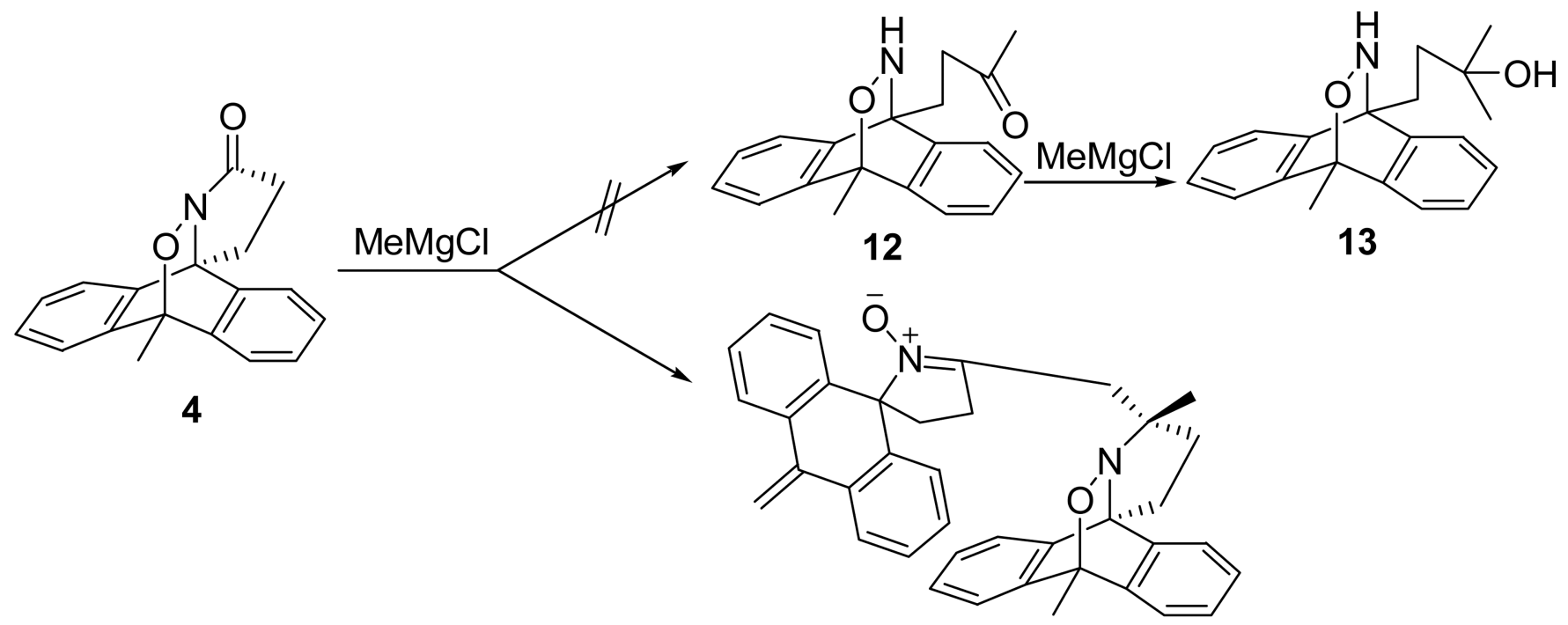

14

Scheme 3. 


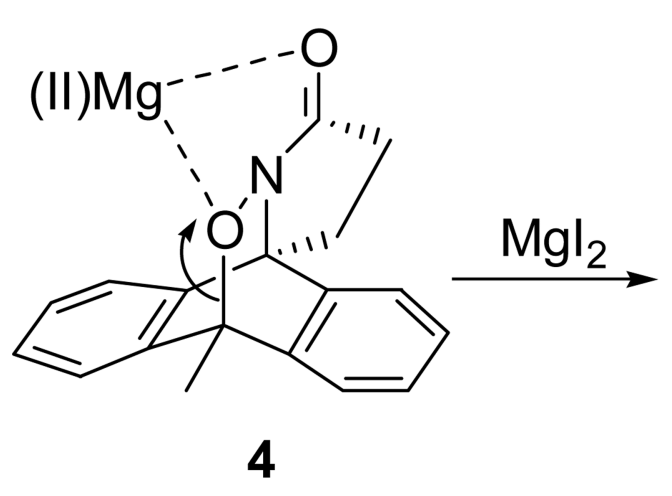

4

Scheme 4.

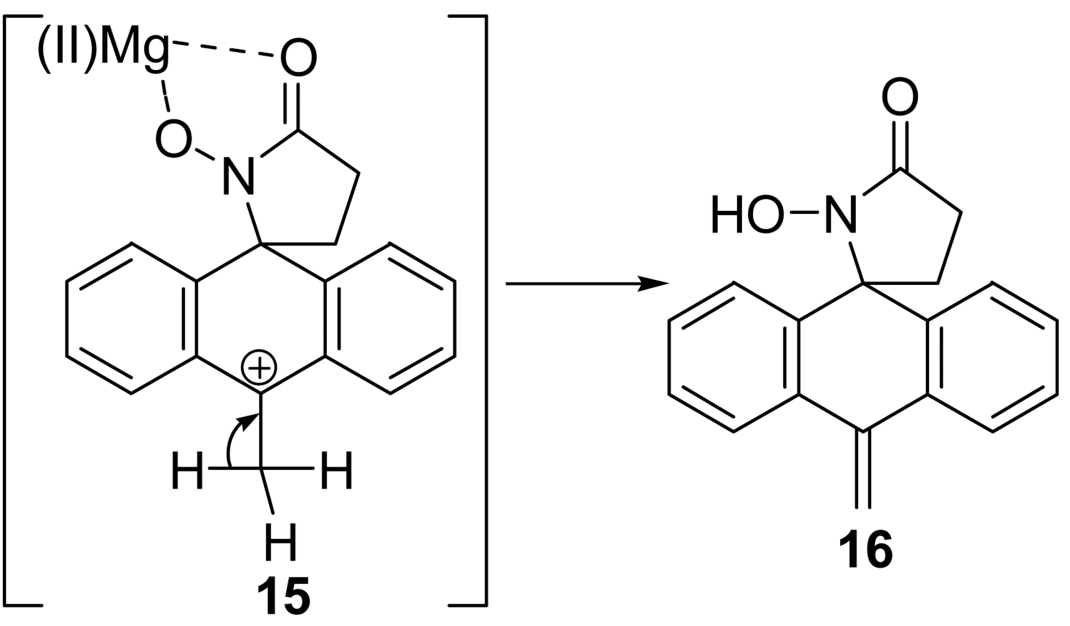




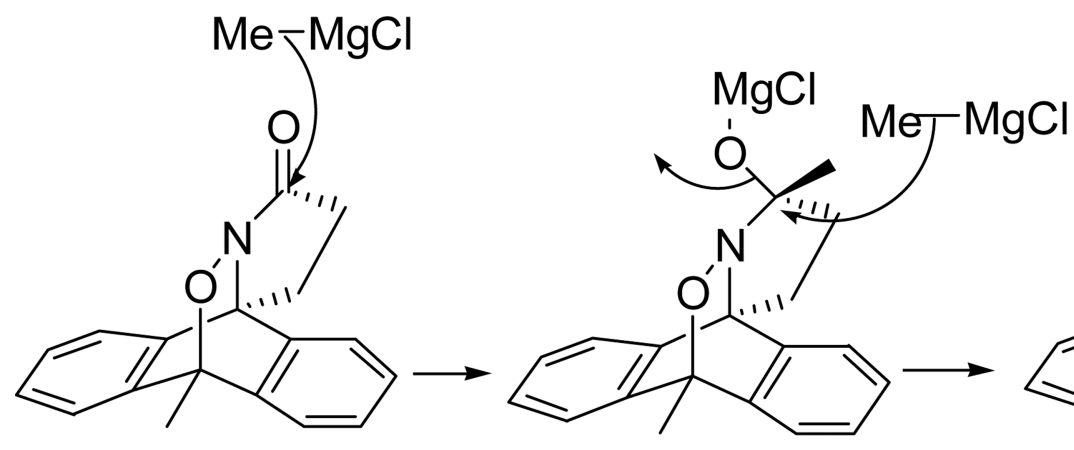

4

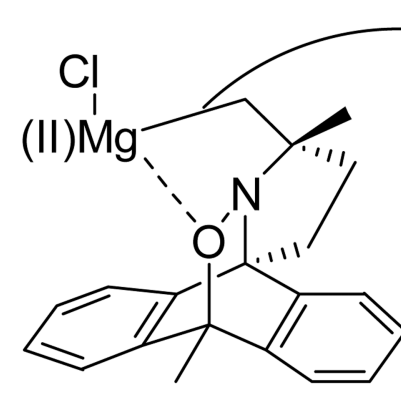

19
17<smiles>C=C1c2ccccc2C2(CCC(=O)N2O)c2ccccc21</smiles>

16

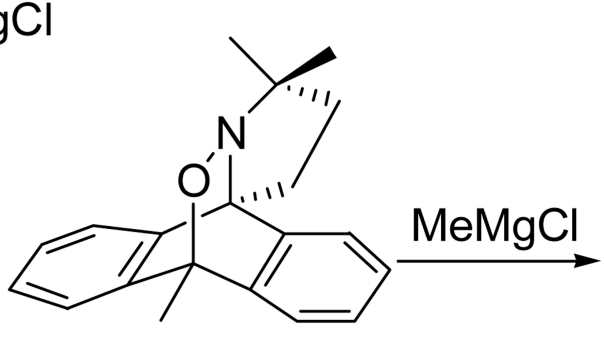

18

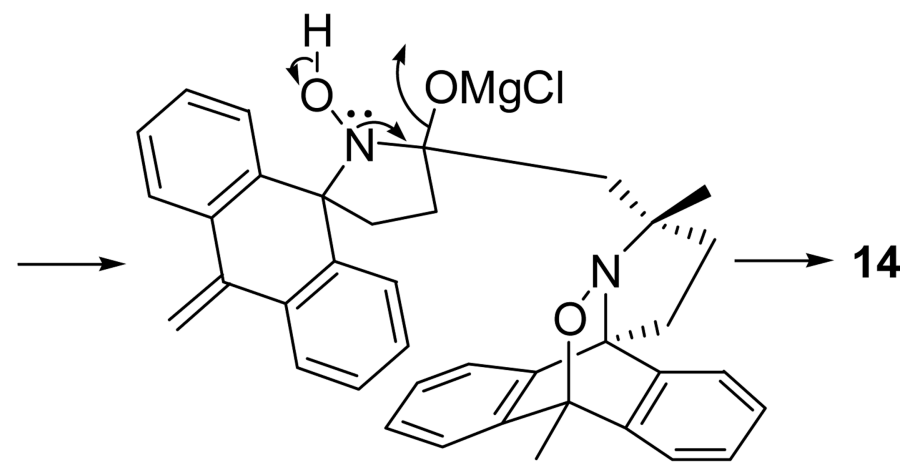

20

Scheme 5. 